\title{
Desain Alat Pengolahan Air Sadah di Desa Berakit
}

${ }^{1}$ Friska Septiani Silitonga, ${ }^{2}$ Eka Putra Ramdhani, Trimas Manalu, ${ }^{4}$ Nina Adriani

${ }^{1,2,3,4}$ Universitas Maritim Raja Ali Haji. Jalan Raya Dompak - Tanjungpinang 29111, Provinsi Kepulauan Riau.

Email Korespondensi: friska.septiani89@umrah.ac.id

\begin{tabular}{|c|c|}
\hline Article Info & Abstract \\
\hline $\begin{array}{l}\text { Article History } \\
\text { Received: } 25-09-2019 \\
\text { Revised: 10-10-2019 } \\
\text { Published: } 28-02-2020\end{array}$ & \multirow{2}{*}{$\begin{array}{l}\text { Design of Hard Water Treatment Equipment in Berakit Village. Water was } \\
\text { an important component for carrying out daily activities. Some quality } \\
\text { parameters of water were physical, chemical and biological parameters. One } \\
\text { of the chemical parameters of water quality was water hardness. The problems } \\
\text { that occured in Desa Berakit, the water used contains } \mathrm{Ca}^{2+} \text { and } \mathrm{Mg}^{2+} \text { ions as } \\
\text { indicated by the reduced washing ability of the soap and produces crust on the } \\
\text { wall of the kettl/ pot when cooking water which is detrimental to the residents. } \\
\text { Therefore the purpose of Community Service aimed to produce tool that can } \\
\text { treat hard water, provided socialization and training to the community so that } \\
\text { it produces free water from hardness, Ca }{ }^{2+} \text { and } \mathrm{Mg}^{2+} \text { ions. The method of } \\
\text { implementation was carried out by: 1) survey and interview, 2) design of hard } \\
\text { water treatment equipment. The results obtained from this activity were } \\
\text { obtaining information about community water problems caused by hard water } \\
\text { and iron and producing hard water treatment equipment designs. }\end{array}$} \\
\hline $\begin{array}{l}\text { Keywords } \\
\text { Hard water, } \\
\text { tool design, } \\
\text { water quality parameters, } \\
\text { water treatment. }\end{array}$ & \\
\hline InformasiArtikel & $\mathbf{K}$ \\
\hline $\begin{array}{l}\text { SejarahArtikel } \\
\text { Diterima: } 25-09-2019 \\
\text { Direvisi: } 10-10-2019 \\
\text { Dipublikasi: } 28-02-2020\end{array}$ & \multirow{2}{*}{$\begin{array}{l}\text { Air merupakan komponen penting untuk melakukan aktivitas sehari-hari } \\
\text { Beberapa parameter kualitas air yaitu paramater fisika, kimia dan biologi. Salah } \\
\text { satu parameter kimia kualitas air yaitu kesadahan air. Permasalahan yang } \\
\text { dihadapi oleh warga Desa Berakit yaitu air yang digunakan mengandung ion } \\
\mathrm{Ca}^{2+} \text { dan } \mathrm{Mg}^{2+} \text { yang ditunjukkan dengan berkurangnya kemampuan mencuci } \\
\text { dari sabun dan menghasilkan kerak di dinding ketel/panci saat pemasakan air } \\
\text { sehingga merugikan warga. Oleh sebab itu tujuan dari Pengabdian kepada } \\
\text { Masyarakat ini bertujuan untuk menghasilkan alat yang dapat mengolah air } \\
\text { sadah, pemberian sosialisasi dan pelatihan kepada masyarakat sehingaa } \\
\text { dihasilkan air yang bebas dari kesadahan yaitu ion } \mathrm{Ca}^{2+} \text { dan } \mathrm{Mg}^{2+} \text {. Metode } \\
\text { pelaksanaan ini dilakukan dengan metode: 1) survey dan wawancara, 2) desain } \\
\text { alat pengolahan air sadah. Hasil yang diperoleh dari kegiatan ini yaitu } \\
\text { mendapatkan informasi mengenai permasalahan air warga yang disebabkan } \\
\text { oleh air sadah dan besi serta menghasilkan desain alat pengolahan air sadah. }\end{array}$} \\
\hline $\begin{array}{l}\text { Kata kunci } \\
\text { Air sadah, } \\
\text { desain alat, } \\
\text { parameter kualitas } \\
\text { pengolahan air. }\end{array}$ & \\
\hline
\end{tabular}

Sitasi: Silitonga S.,F., Ramdhani P.,E., Manalu T., \& Andriani N., (2020) Desain Alat Pengolahan Air Sadah di Desa Berakit. Sasambo: Jurnal Abdimas (Journal of Community Service). 2(1), 7-11. Doi: 10.36312/sasambo.v1i2.134

\section{PENDAHULUAN}

Air merupakan komponen yang paling dibutuhkan makhluk hidup dalam kehidupan. Untuk memenuhi kebutuhan makhluk hidup maka air dibutuhkan dalam jumlah besar. Air digunakan untuk kebutuhan rumah tangga, kegiatan industri, dan sebagainya. Pemanfaatan air dalam kehidupan dikategorikan sebagai kebutuhan rumah tangga dan industri yang 
memiliki beberapa kriteria. Kriteria kualitas air bersih yaitu memenuhi syarat secara fisik, kimia, dan mikrobiologi (Athena, dkk, 2004). Indikator kualitas air yaitu tidak berasa, tidak berwarna, tidak berbau, $\mathrm{pH}$ netral 7-8,2, bebas dari mikroorganisme, bebas dari logam berat, dan bebas dari kesadahan air. Indikator ini digunakan sebagai parameter air dikatakan bersih. Permasalahan yang ditemukan pada perairan warga Desa Berakit yaitu : 1) air berwarna kecoklatan, 2) air berbau karat, 3) $\mathrm{pH}$ rendah sekitar 4-5, 4) air merupakan air sadah sehingga mengakibatkan penggunaan sabun yang lebih banyak yang diakibatkan menurunkan daya pencuci sabun sehingga kinerja sabun menjadi tidak efektif.

Kondisi air yang tidak sesuai dengan parameter dan indikator kualitas air yang dipergunakan masyarakat selama ini untuk aktivitas rumah tangga sehari-hari. Hal yang ditimbulkan dari kondisi air yang digunakan masyarakat dapat menyebabkan keropos pada gigi yang disebabkan oleh $\mathrm{pH}$ air rendah atau asam, meninggalkan bercak pada pakaian, menurunkan daya pencuci sabun, bagi kesehatan dapat menyumbat pembuluh darah jantung (cardiovascular desease) dan batu ginjal (urolithiasi). Oleh sebab itu diperlukan suatu alat yang dapat digunakan untuk pengolahan air sadah yang sederhana di desa Berakit. Alat yang dirancang sederhana menggunakan aerasi dan metode adsorpsi dengan menggunakan karbon aktif. Karbon aktif dapat dimanfaatkan sebagai adsorben karena memiliki pori. Berdasarkan penelitian yang dilakukan oleh Apriani dkk., (2013) karbon aktif dapat menyerap Fe (II) di air gambut. Tujuan dari kegiatan ini adalah merancang alat sederhana yang dapat digunakan untuk pengolahan air di desa Berakit sehingga kualitas air yang digunakan memenuhi indikator kualitas air yang baik

\section{METODE PELAKSANAAN}

Metode yang digunakan dalam kegiatan ini yaitu 1) Survey dan Wawancara.Pada tahap survey dan wawancara dilakukan dengan tujuan untuk mendapatkan informasi permasalahan yang dihadapi oleh masyarakat desa Berakit serta gambaran perairan yang digunakan oleh masyarakat. Setelah tahapan survey dan wawancara maka dilakukan tahapan pembuatan rancangan alat pengolahan air sederhana. 2) Pembuatan Rancangan Alat.Tahap perancangan alat dilakukan dengan tujuan untuk menentukan desain alat yang tepat untuk pengolahan air sadah secara otomatis. Hasil kajian dari survey yang telah dilakukan digunakan untuk menentukan desain alat tersebut sehingga benar-benar dapat menjadi solusi dalam pengolahan air sadah. Berdasarkan pengkajian, otomatisasi pengolahan air sadah memerlukan mikrokontroler sebagai sistem elektronik pengontrolan pengolahan air sadahsecara otomatis. Perancangan alat pengolahan air sadah terdiri dari 3 bagian, yaitu bagian tandon pengendapan air sadah, bagian tabung filter air, dan bagian tangki air. Keseluruhan bagian dirangkai menjadi sebuah sistem yang saling terhubung.3) Pembuatan Model Perangkat. Tahap model perangkat merupakan tindak lanjut dari tahap rancangan alat sesuai dengan desain alat yang didapatkan. Untuk melakukan pengolahan air sadah secara otomatis diperlukan alat dan bahan berikut ini

Tabel 1. Alat dan bahan

\begin{tabular}{llll}
\hline No & Nama & No & Nama \\
\hline 1 & Tandon air 250 liter & 9 & Tabung filter air \\
2 & Tabung filter air & 10 & Tangki air 100 liter \\
3 & Tangki air 100 liter & 11 & Mikrokontroler Arduino Nano \\
4 & Mikrokontroler Arduino Nano & 12 & Aerator \\
5 & Aerator & 13 & Box Auto Feeder \\
6 & Box Auto Feeder & 14 & Kran listrik $1 / 2$ inch \\
\hline
\end{tabular}




\begin{tabular}{llll}
\hline 7 & Kran listrik $1 / 2$ inch & 15 & Kabel \\
8 & Tandon air 250 liter & 16 & Kran air $1 / 2$ inc
\end{tabular}

\section{HASIL DAN PEMBAHASAN}

Berdasarkan hasil survey, wawancara dengan masyarakat desa Berakit diperoleh informasi bahwa kondisi perairan yang selama ini digunakan meninggalkan bercak pada pakaian, memerlukan jumlah sabun yang banyak apabila digunakan untuk mencuci, meninggalkan kerak pada ketel ketika proses pemasakan air, serta air yang digunakan berbau karat. Adapun gambaran dari perairan desa Berakit dapat dilihat pada Gambar 1 beriku

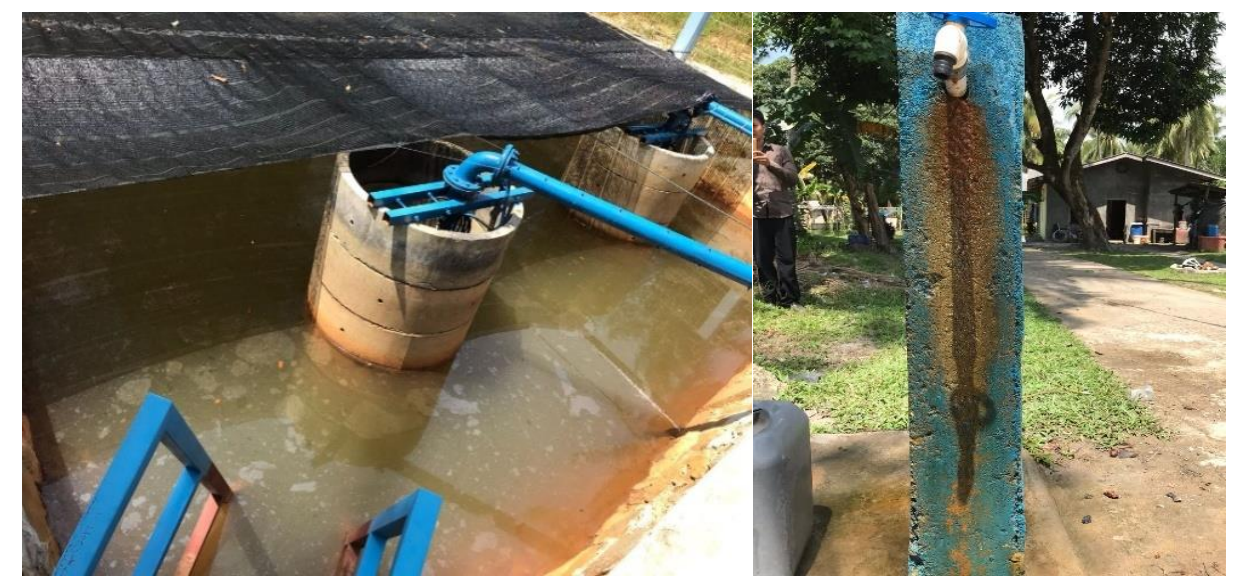

Gambar 1. Kondisi air yang digunakan masyarakat Desa Berakit

Berdasarkan PerMenkes No 32 tahun 2017, maka kualitas air yang baik digunakan yaitu tidak berasa, tidak berbau, $\mathrm{pH}$ 7-7,8 sedangkan $\mathrm{pH}$ air yang digunakan oleh warga yaitu dibawah pH 6 sehingga tidak baik digunakan dalam aktivitas sehari-hari. Selain itu, air ini juga mengandung ion besi yang menyebabkan air berwarna kecoklatan. Oleh sebab itu, logam ini sebaiknya dihilangkan dari perairan yang digunakan oleh masyarakat desa Beraki.

Untuk mengatasi permasalahan ini, maka dirancang suatu alat pengolahan air sederhana yang dapat digunakan oleh masyarakat untuk menghilangkan mineral seperti kalsium, dan besi yang berada dalam perairan. Hasil rancangan alat yang dapat diimplementasikan dalam pengolahan air sadah di Desa Berakit dapat dilihat pada Gambar 2.

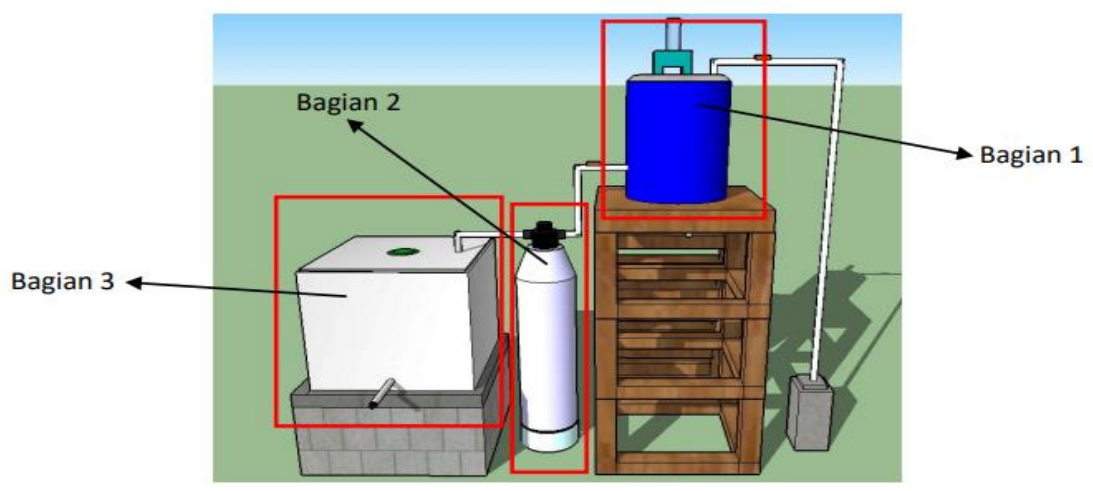

Gambar 2. Model Perangkat Pengolahan Air Sadah 


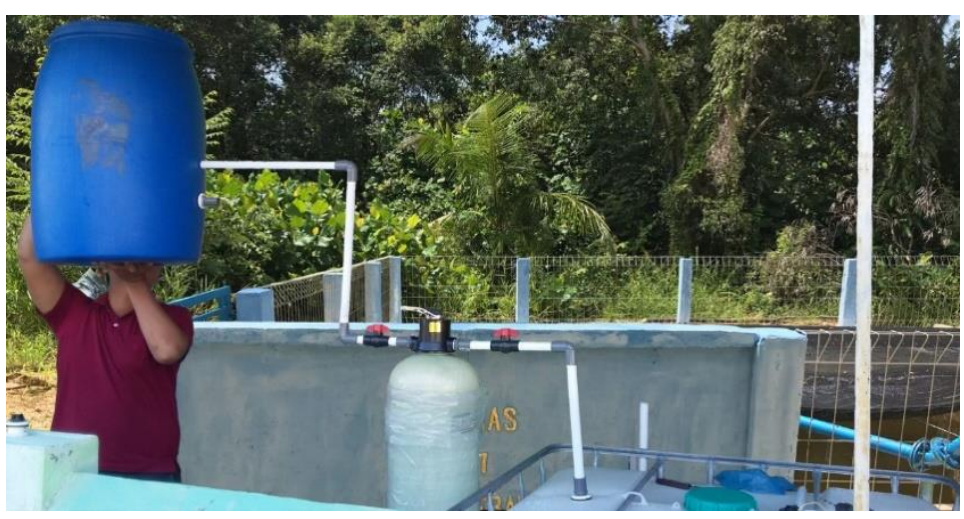

Gambar 3. Perancangan Alat Pengolahan Air Sadah

Pada gambar 2 terdapat 3 bagian dalam proses pengolahan air sadah. Bagian 1 terdiri dari tandon air 250 liter, mikrokontroler, aerator, dan auto feeder. Pada bagian 1, aerator berfungsi untuk proses aerasi yang mampu menyediakan oksigen, dan auto feeder digunakan untuk memasukkan natrium karbonat sehingga ketika air yang dikontakkan dengan oksigen dapat bereaksi dengan natrium karbonat dan membentuk senyawa kalsium karbonat yang berupa endapan dan dikeluarkan dari Bagian 1. Selanjutnya air yang dilewatkan ke Bagian 2. Bagian 2 merupakan tabung filter air sebagai media pasir halus $20 \mathrm{~kg}$ dan karbon aktif $10 \mathrm{~kg}$. Penggunaan pasir halus untuk proses filtrasi bahan-bahan padat yang belum terlewatkan pada Bagian 1 dan karbon aktif pada tabung filter bertujuan untuk proses adsorpsi logam atau ion besi yang terdapat pada air dan menghilangkan bau pada air. Karbon aktif berfungsi sebagai adsorben yang memiliki pori yang dapat menyerap Fe(II) pada air hal ini sesuai dengan penelitian yang dilakukan oleh Apriani dkk (2013) yang menunjukkan penyerapan sebesar $85,36 \%$. Bagian 3 merupakan bagian terakhir dari proses pengolahan air sadah yang terdiri dari tangki air dengan ukuran 1000 liter. Air yang masuk ke dalam tangki ini merupakan air yang sudah layak untuk di konsumsi oleh warga Desa Berakit.

Mikrokontroler Arduino Nano yang terdapat pada bagian 1 akan mengontrol kran listrik, auto feeder, dan aerator bekerja. Selama sistem bekerja maka aerator akan aktif dan auto feeder akan mengeluarkan natrium karbonat berkisar 9 gr / 250 liter air. Hal ini dilakukan untuk mempercepat proses pengendapan air sadah. Pada perancangan perangkat ada 3 kran listrik. Peletakan kran listrik pada perangkat dapat dilihat pada Gambar4.

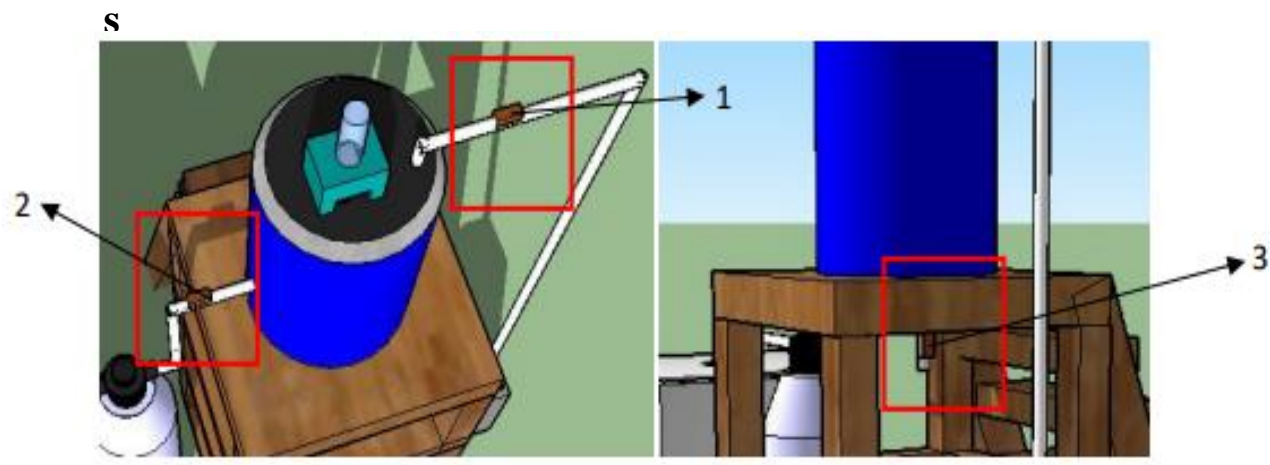

Gambar 4. Peletakan Kran Listrik

Pengontrolan kran listrik pada Gambar4 menggunakan estimasi waktu menggunakan mikrokontroler. Pada saat tandon air dalam keadaan kosong, kran listrik 1 akan bekerja selama 15 menit untuk mengisi tandon air hingga penuh. Waktu yang dibutuhkan didapatkan berdasarkan besar debit air yang masuk ke dalam tandon. Pada kondisi ini aerator akan aktif dan auto feeder mengeluarkan natrium karbonat berkisar 9 gr. Setelah 15 menit berlangsung maka keran listrik 1 tidak bekerja dan dibutuhkan waktu sekitar 2 jam untuk proses 
pengendapan. Setelah 2 jam berlangsung maka mikrokontroler akan mengaktifkan kran listrik 2 selama 20 menit untuk mengalirkan air dari tandon ke dalam tabung filter. Air yang masuk ke dalam tabung filter langsung dialirkan ke dalam tangki dalam keadaan air layak konsumsi. Setelah 20 menit berlangsung, maka mikrokontroler akan mengaktifkan kran listrik 3 selama 5 menit. Hal ini dilakukan untuk membuang sisa endapan yang ada di dalam tandon air. Mikrokontroler akan memproses keadaan tersebut berulang-ulang hingga tangki air penuh dan sistem dapat di non aktifkan melalui saklar listrik yang digunakan

\section{KESIMPULAN}

Berdasarkan hasil kegiatan ini diperoleh air yang baik sesuai kualitas air yang dipersyaratkan yaitu tidak berbau, tidak berasa, $\mathrm{pH}$ netral sekitar 7-7,8 dan tidak mengandung logam berat atau mineral penyebab kesadahan yang dapat merugikan masyarakat dan juga kesehatan masyarakat.

\section{UCAPAN TERIMA KASIH}

Ucapan terima kasih kepada Universitas Maritim Raja Ali Haji melalui Hibah Internal Pengabdian Kepada Masyarakat tahun 2018 yang telah memberikan dana pada kegiatan ini, hingga dapat terselesaikan sesuai dengan rencana dan target luaran.

\section{DAFTAR PUSTAKA}

Apriani, R., Faryuni, I,D., dan Wahyuni, D., 2013, Pengaruh Konsentrasi Aktivator Kalium Hidroksida $(\mathrm{KOH})$ terhadap Kualitas Karbon Aktif Kulit Durian sebagai Adsorben Logam Fe pada Air Gambut, Jurnal Prisma Fisika, 1 (2): 82-86. http://jurnal.untan.ac.id/index.php/jpfu/article/view/2931

Athena, S., Hendro, M., Anwar, M., dan Haryono, 2004, Kandungan Bakteri Total Coli dan E. coli/ Fecal coli Air, Skripsi. Universitas Tanjungpura, Pontianak

Bakr, A.A., Makled,W.A., Kamel, M.M., (2015), Seawater-softening process through formation of calcite ooids. Egyptian J. Of Petroleum, 24, pp 29-25

Dewa, I.G.N., Komang A.N., Putu A.S.W., (2012), Analisis Mutu Air Minum Isi Ulang di Kecamatan Kuta Selatan Kabupaten Badung Bali, J. Teknologi Pangan, 3, pp 1-2, https://ojs.unud.ac.id/index.php/itepa/article/view/8869

Gabrielli,C., Mauri, G., Francy, H., Chausson., Thery, P., Tran, T,T,M., Tlili, M., (2006), Electrochemical water softening: principle and aplication. J.Desalination, 201, pp 150163

Shestak I.V., Vorobiev P.D., Cherednichenko D.V., Vorobieva E.V., Bondareva G.V., Stradnova N. (2011). Effect of polyacrilic acid and polyethylene glycol on the crystallization of calcium carbonates in the presence of magnesium ions. Russian Journal of Inorganic Chemistry.56: 2, p.176 - 180

Sulistyani, Sunarto, Annisa, F., (2012), Uji Kesadahan Air Tanah di Daerah Sekitar Pantai Kecamatan Rembang Propinsi Jawa Tengah, J. Sains Dasar, 1(1), 33-38. 